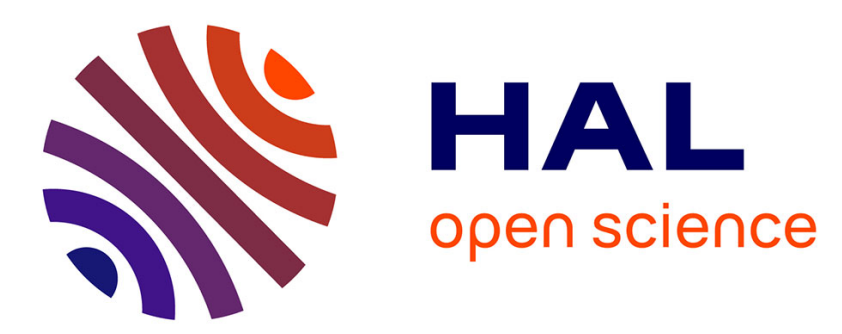

\title{
Étude des réactions nucléaires à l'aide d'un télescope à coincidences induites par des neutrons de $14 \mathrm{MeV}$ P. Lévy, Cédric Bonnel
}

\section{To cite this version:}

P. Lévy, Cédric Bonnel. Étude des réactions nucléaires à l'aide d'un télescope à coincidences induites par des neutrons de $14 \mathrm{MeV}$. J. Phys. Phys. Appl., 1961, 22 (S11), pp.155-155. 10.1051/jphysap:019610022011015501 . jpa-00212837

\section{HAL Id: jpa-00212837 https://hal.science/jpa-00212837}

Submitted on 1 Jan 1961

HAL is a multi-disciplinary open access archive for the deposit and dissemination of scientific research documents, whether they are published or not. The documents may come from teaching and research institutions in France or abroad, or from public or private research centers.
L'archive ouverte pluridisciplinaire HAL, est destinée au dépôt et à la diffusion de documents scientifiques de niveau recherche, publiés ou non, émanant des établissements d'enseignement et de recherche français ou étrangers, des laboratoires publics ou privés. 
LE JOURNAL DE PHYSIQUE ET LE RADIUM PHYSIQUE APPLIQUÉE
SUPPLÉMENT AU N 11. TOME 22, NOVEMBRE 1961, PAGE 155 A.

ÉTUDE DES RÉACTIONS NUCLÉAIRES

\section{A L'AIDE D'UN TÉLESCOPE A COINCIDENCES INDUITES PAR DES NEUTRONS DE $14 \mathrm{MeV}$}

Par P. LÉVY et C. BONNEL, Laboratoire de Synthèse Atomique et d'Optique Protonique, Ivry.

Résumé. - On décrit une installation destinée à l'étude des répartitions angulaires des particules chargées émises lors de réactions nucléaires produites par des neutrons de $14 \mathrm{MeV}$. (Le flux de neutrons est mesuré par la méthode de la particule associée.) Le détecteur est un télescope à coïncidences à deux compteurs proportionnels et un scintillateur. L'identification des particules est obtenue en traçant électroniquement sur un oscilloscope les courbes $E=f\left(\frac{\partial E}{\partial x}\right)$. On utilise l'optique d'une caméra Dumont, à la fois pour réaliser un cache photographique sélectionnant une courbe caractéristique des particules et pour former l'image de l'écran sur ce même cache, regardé par un photomultiplicateur. Une discrimination de l'amplitude des impulsions lumineuses permet d'ajuster le degré d'élimination des particules. Comme test de l'installation on montre les résultats obtenus dans l'étude des réactions ${ }^{19} \mathrm{~F}(\mathrm{n}, \mathrm{p}){ }^{18} \mathrm{O}$ et $\mathrm{D}(\mathrm{n}, 2 \mathrm{n}) \mathrm{H}$.

Abstract. - We describe an installation intended for the study of the angular distributions of charged particles send out from reactions with $14 \mathrm{MeV}$ neutrons. (The neutron flux is measured by the associated particle method.) The detector is a coincidence telescope with two proportional counters and one scintillator. The identification of the particles is obtained by electronic tracing on an oscilloscope of the curve $E=f\left(\frac{\partial E}{\partial x}\right)$. We use the optical systeme of a Dumont Camera at the same time to produce a photographic mask selecting a caracteristic curve of one particle and to form the picture of the screan on this same mask, viewed by a photomultiplier. Discrimination of the luminous pulse amplitude permits us to adjust the degree of particle elimination. As a test of the installation, we show results obtained in the study of the reactions ${ }^{19} \mathrm{~F}(\mathrm{n}, \mathrm{d}){ }^{18} \mathrm{O}$ and $\mathrm{D}(\mathrm{n}, 2 \mathrm{n}) \mathrm{H}$.

(Paru au Journal de Physique et le Radium 1961, 22, 489). 